\title{
The influence of changes in the degree and frequency of disturbance on the annual salt marsh plant (Suaeda maritima, Artemisia fukudo) communities in estuarine tidal flats: A case study of the Kushida River in Mie Prefecture, Japan
}

\author{
Korehisa Kaneko $^{1^{*}}$, Seiich Nohara ${ }^{2}$ \\ ${ }^{1}$ Ecosystem Conservation Society_Japan, Tokyo, Japan; * Corresponding Author: $\mathrm{k}$ kaneko@hotmail.com \\ ${ }^{2}$ Center for Environmental Biology and Ecosystem Studies, National Institute for Environmental Studies, Tsukuba City, Japan
}

Received 7 November 2013; revised 7 December 2013; accepted 15 December 2013

Copyright (c) 2014 Korehisa Kaneko, Seiich Nohara. This is an open access article distributed under the Creative Commons Attribution License, which permits unrestricted use, distribution, and reproduction in any medium, provided the original work is properly cited. In accordance of the Creative Commons Attribution License all Copyrights (C) 2014 are reserved for SCIRP and the owner of the intellectual property Korehisa Kaneko, Seiich Nohara. All Copyright (C) 2014 are guarded by law and by SCIRP as a guardian.

\section{ABSTRACT}

In this study, we examined the influence of changes in the degree and frequency of disturbance in estuarine tidal flats on the annual salt marsh plant communities (Suaeda maritima, Artemisia fukudo) in Mie Prefecture, Japan. Suaeda maritima and Artemisia fukudo communities occur in the branch river of the Kushida River. Although the areas occupied by these communities were very small in 2006, the Suaeda maritima community expanded significantly to $3609 \mathrm{~m}^{2}$ in 2008, and the Artemisia fukudo community expanded significantly to $\mathbf{2 7 2 6}$ $\mathrm{m}^{2}$ in 2008 and $10,396 \mathrm{~m}^{2}$ in 2010. Before the onset of the investigation period in 2006, the overflow warning water level $(3.5 \mathrm{~m})$ and the flood fighting corps standby water level $(3.0 \mathrm{~m})$ each occurred on one day in August 2004 and October 2004, respectively; at those times, the water volume exceeded $1000 \mathrm{~m}^{3} \cdot \mathrm{s}^{-1}$ and 1500 $\mathrm{m}^{3} \cdot \mathrm{s}^{-1}$, respectively. We suggest that because much of the estuarine tidal flat erodes when the water volume exceeds $1000 \mathrm{~m}^{3} \cdot \mathrm{s}^{-1}$, the establishment of the Suaeda maritima and Artemisia fukudo communities is delayed until sufficient substrate is formed by the deposition of new sediment. In contrast, a water level of 2 - $3 \mathrm{~m}$ was observed on one day each in 2005, 2007 and 2009 , with average water volumes of $488.5,566.4$ and $690.1 \mathrm{~m}^{3} \cdot \mathrm{s}^{-1}$, respectively. We suggest that following the repeated disturbances caused by water levels of $1-3 \mathrm{~m}$ and flow volumes of 500 $700 \mathrm{~m}^{3} \cdot \mathrm{s}^{-1}$ over the bare ground exposed after flooding and erosion, Suaeda maritima is a pioneer species that colonizes on bare ground deposited by sediment transported from upstream and the sea during high tides, and following the same level of disturbance, Artemisia fukudo is secondary colonizer that has germinated and grown on the sediment deposited on the Suaeda maritima community.

\section{KEYWORDS}

Annual Salt Marsh Plant; Disturbance; Flow Volume; Water Level; Vegetation Change

\section{INTRODUCTION}

Many salt marsh plants are found in the estuarine tidal flat of the Kushida River, including the annual plants Suaeda maritima and Artemisia fukudo. These species are listed as Red Data Book species by [1,2]. In recent years, these species have undergone declines due to coastal development, bank protection and other factors. Several environmental factors influence the habitat preferences of plants in estuarine tidal flats, including elevation and flood frequency [3], soil environment (salinity, humidity, particle size distribution, depth, oxidation-reduction potential), disturbance by floods, competition with other plants and other factors 
$[4,5]$. The composition of the salt marsh plant community is influenced by sediment dynamics and the physical environment [6,9]. In particular, the distributions of Suaeda maritima and Artemisia fukudo communities in Kushida River varied greatly among the study years of 2006, 2008 and 2010. These species broadly distributed in estuarine tidal flats with high flow volumes and water levels [10]. Consequently, we hypothesized that changes in the degree and frequency of disturbances through changes in water volume and water level extremes influence the distributions of Suaeda maritima and Artemisia fukudo; however, few detailed studies have been conducted on this process.

In this study, we examined the influence of changes in the degree and frequency of disturbance in estuarine tidal flats on the distribution of annual salt marsh plants (Suaeda maritima, Artemisia fukudo). In particular, we investigated the effects of water volume and water level, which are considered the main environmental influences on distribution in these communities, and assessed the effects of disturbance on distribution change in the estuarine tidal flats of the Kushida River.

\section{STUDY SITES AND METHODS}

\subsection{Study Site}

The Kushida River is a first-class river that is $85 \mathrm{~km}$ long, with a basin area of $461 \mathrm{~km}^{2}$. The river flows through Mathuzaka City in Mie Prefecture. The headwaters are on Takami Mountain (altitude $1249 \mathrm{~m}$ ), located on the border of Higashiyoshino, Yoshino District, Nara Prefecture and Mathuzaka City in Mie Prefecture, and the river empties into Ise Bay.

The study site was chosen because it is readily disturbed by river flooding in the estuarine tidal flat of the Kushida River (Figure 1).

\subsection{Vegetation Sampling Methods}

The vegetation survey was conducted during July of 2006, 2008 and 2010. The vegetation map was created

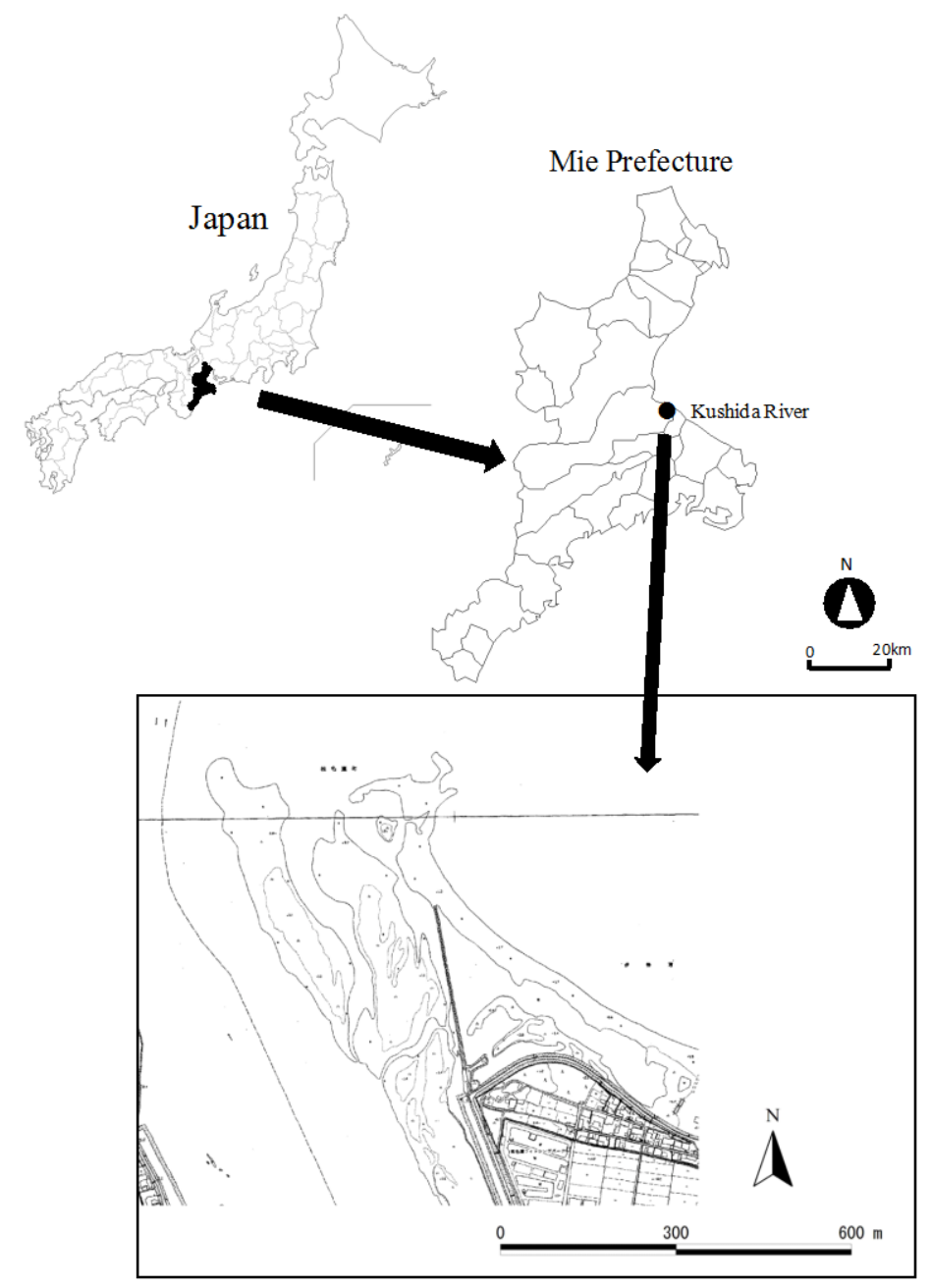

Figure 1. Study site location. 
based on the plant communities observed in aerial photographs; local confirmation of the plant community was conducted in cases where discrimination based on aerial photographs was difficult. We surveyed the study site to map the distribution of plant communities (1:2500). Vegetation data were used to develop a physiognomic vegetation map using GIS (Arc-View 3.1).

Data on water volume and water level were obtained from the observation station near the estuarine tidal flats. For the period of observation under analysis, we assumed that changes to the river environment preceding the survey had a large influence on the delta. Therefore, we used the data spanning the period from July 2004 to July 2010.

Normal water levels were classified into 0 - $1 \mathrm{~m}, 1$ - 2 m, 2 - 3 m, flood fighting corps standby water level (3 m) and flooding warning water level $(3.5 \mathrm{~m})$ categories [11].

\subsection{Classification of Vegetation Types}

The vegetation types were classified as either 1) salt marsh plants or 2) exotic and upland plants (herbs). Salt marsh plants were defined as plants growing in the areas surrounding marshes and bogs near the mouth of the lagoon and river in the coastal zone, and upland plants were classified as plants growing in areas of strong anthropogenic influence, such as reclaimed areas [12] and environments with low soil moisture [13]. Exotic plants were defined as plants brought in from foreign countries, and it is generally assumed that these plants were introduced after the Edo period in Japan [14]. In addition, we classified the vegetative areas as either soil sedimentation disturbance areas (areas that transitioned from salt marsh plants to terrestrial vegetation or from bare ground to salt marsh vegetation), soil erosion disturbance areas (areas that transitioned from terrestrial vegetation to salt marsh vegetation or from salt marsh vegetation to bare ground) or no vegetation areas (bare ground) to evaluate evidence of disturbance in the vegetation changes of the salt marsh plant - land plant community based on the vegetation division maps of 2006, 2008 and 2010.

\section{RESULTS}

\subsection{Area of the Plant Communities in the Study Site}

The area occupied by the plant communities over the entire study site increased in 2008 to 2010 and in 2006 to 2008; in particular, the areas of the annual salt marsh plant communities of Suaeda maritima and Artemisia fukudo expanded substantially in the branch river. The majority areas of the branch river were occupied by bare land in 2006; in 2008, the Suaeda maritima community expanded; and in 2010, the Artemisia fukudo community expanded (Figures 2 and 3). Relative to the other vegetation types, the area of the annual salt marsh plant

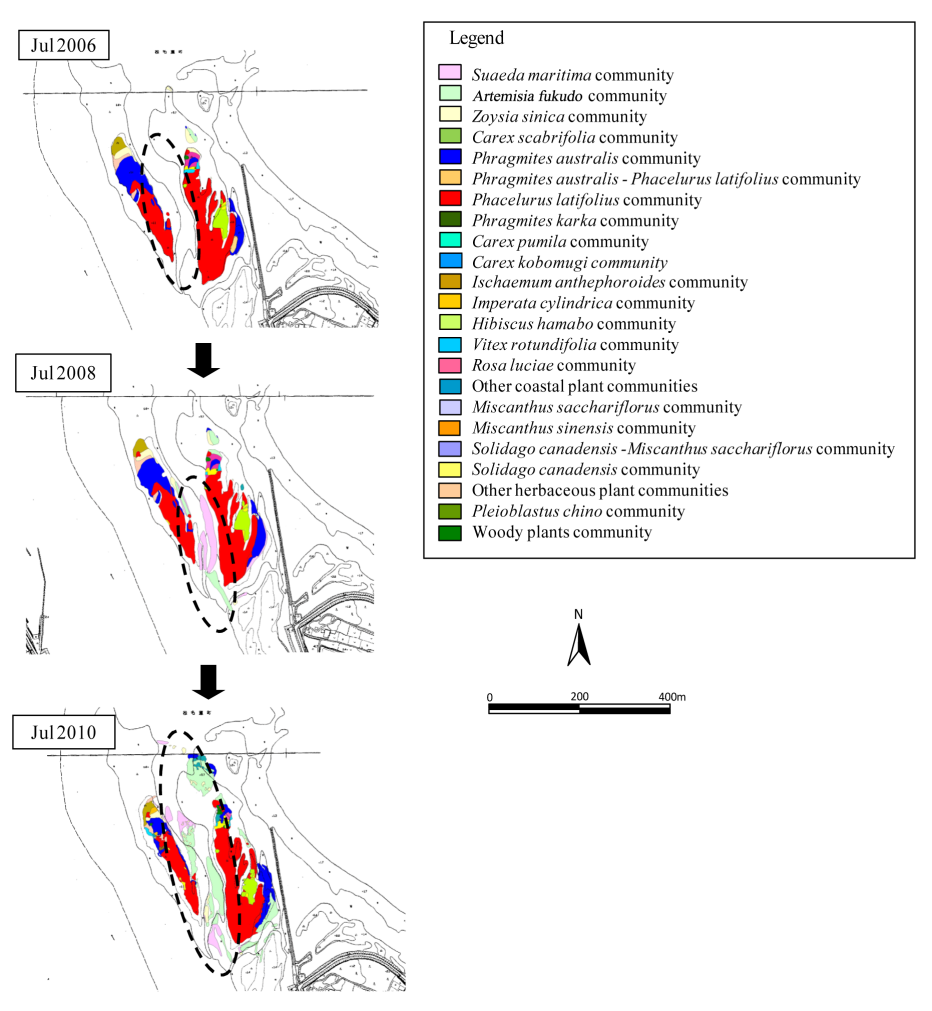

Figure 2. Temporal changes in the vegetation of the Kushida River delta. 


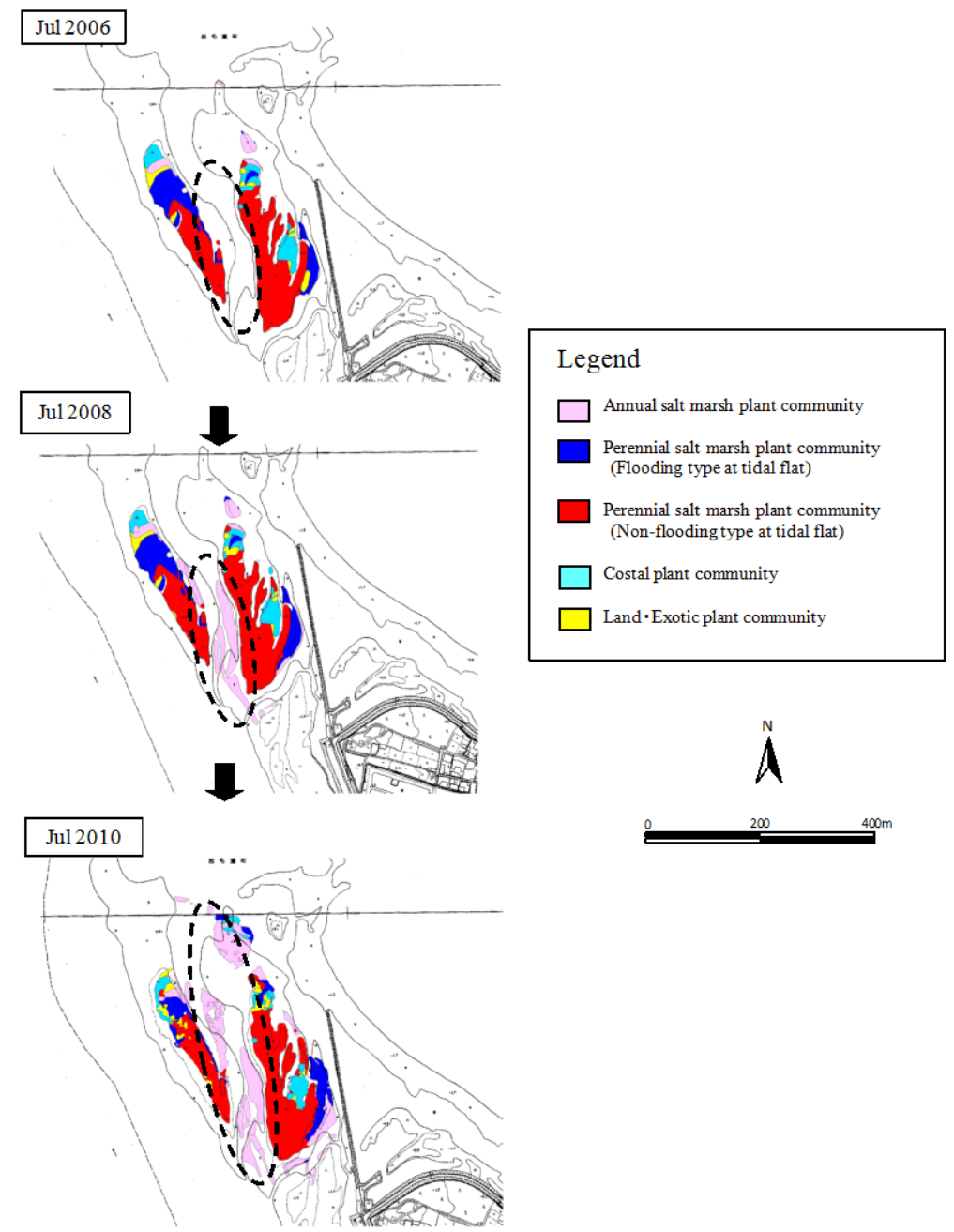

Figure 3. Temporal changes in vegetation type in the Kushida River delta.

community (the area flooded during high tide) increased between 2006 and 2010 (Figure 4). The Suaeda maritima community was not present in 2006; however, it expanded to $3609 \mathrm{~m}^{2}$ in 2008 and decreased to $2,578 \mathrm{~m}^{2}$ in 2010. In contrast, the Artemisia fukudo community expanded substantially from $255 \mathrm{~m}^{2}$ in 2006 to $2,726 \mathrm{~m}^{2}$ in 2006 and 10,396 $\mathrm{m}^{2}$ in 2010 (Table 1, Figure 5).

\subsection{Changes in the Vegetation of the Annual Salt Marsh Plant Community}

Our investigation of the change in the vegetation of the annual salt marsh plant communities (Suaeda maritima and Artemisia fukudo) indicated that the change in area from bare ground to the Suaeda maritima community was highest between 2006 and 2008 and that the change in area from bare ground to the Artemisia fukudo community was highest between 2008 and 2010. In addition, the area of change from bare ground to the Suaeda maritima community and from the Suaeda maritima community to the Artemisia fukudo community both ex- ceeded $2000 \mathrm{~m}^{2}$ (Table 2)

Our investigation of the disturbance status of the entire study area based on vegetation changes indicated that the area of soil sedimentation disturbance was approximately 20\% between 2006 and 2008; however, this area expanded to approximately 45\% between 2008 and 2010 . The area of soil erosion disturbance was $4.8 \%$ between 2006 and 2008 and expanded to $19.3 \%$ between 2008 and 2010. In contrast, the area of no vegetation was in excess of $70 \%$ between 2006 and 2008 and reduced to half that amount between 2008 and 2010 (Figure 6).

\subsection{Changes in Flow Volume and Water Level before and after the Investigation Period}

Water levels exceeded 2 - 3 m primarily in August-October 2004 and exceeded $1.0 \mathrm{~m}$ in September 2005, July 2007 and August and October 2009. During the remaining periods, water levels were below $0.5 \mathrm{~m}$ (Figure 7). Flow volume was $500-1500 \mathrm{~m}^{3} \cdot \mathrm{s}^{-1}$ in August-October 


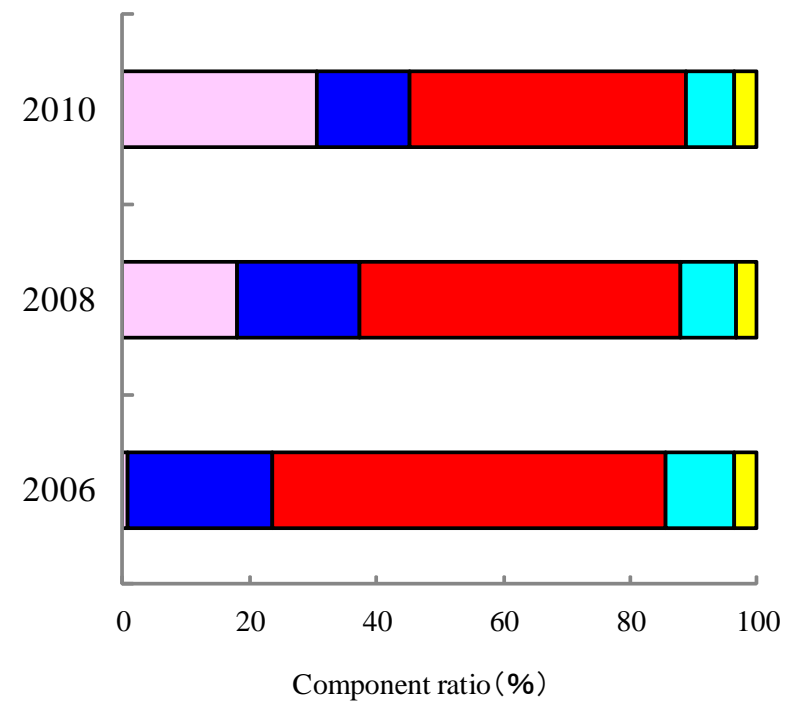

\section{Legend}

Annual salt marsh plant community

Perennial salt marsh plant community

(Flooding type at tidal flat)

Perennial salt marsh plant community (Non-flooding type at tidal flat)

Costal plant community

Land $\cdot$ Exotic plant community

Figure 4. Changes in the component ratio of each vegetation type in the Kushida River delta.

\section{Artemisia fukudo community}

Suaeda maritima community
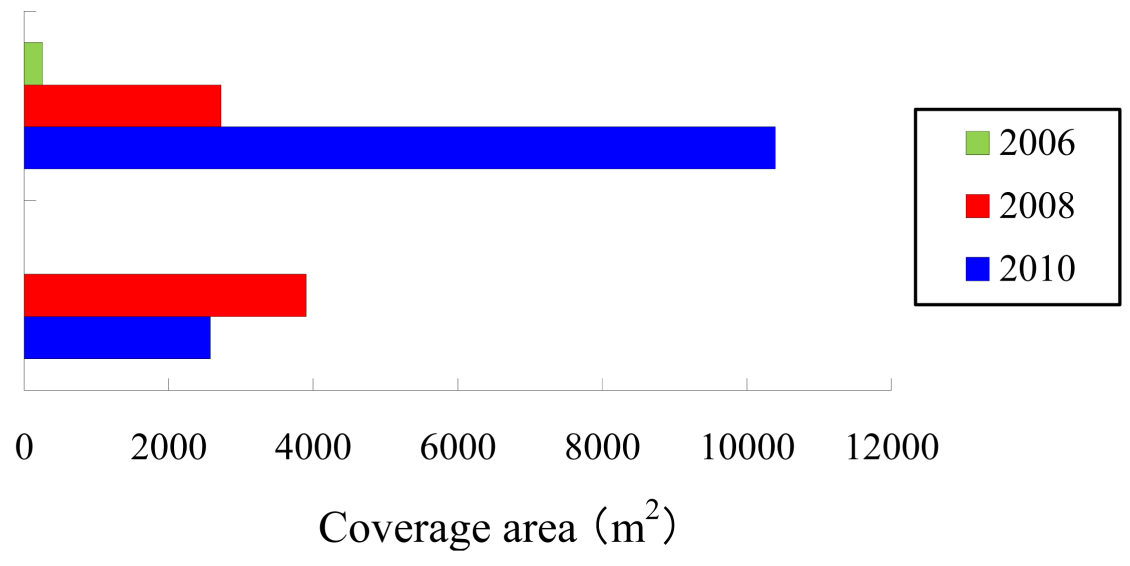

Figure 5. Change in area of the annual salt marsh plant communities in the Kushida River delta.

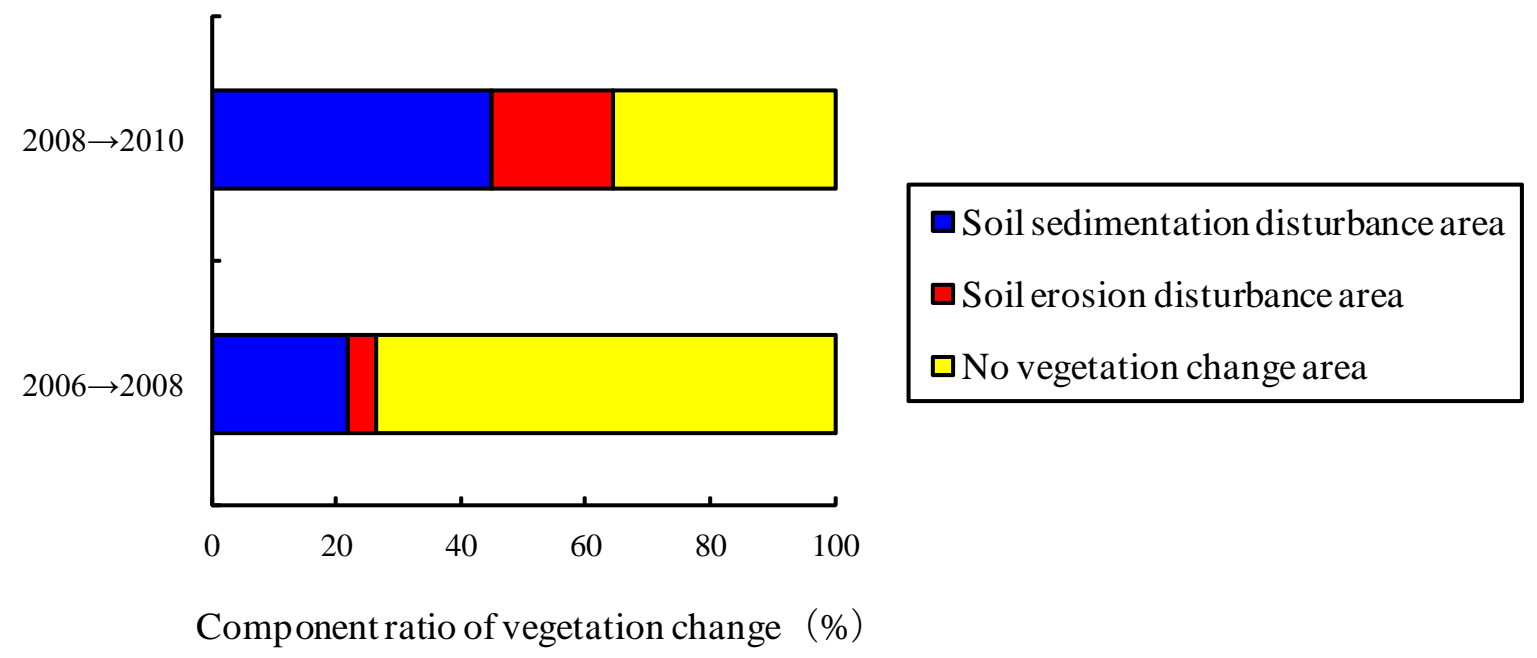

Figure 6. Disturbance areas (Sediment deposition, Sediment erosion, No vegetation) determined based on vegetation changes. 

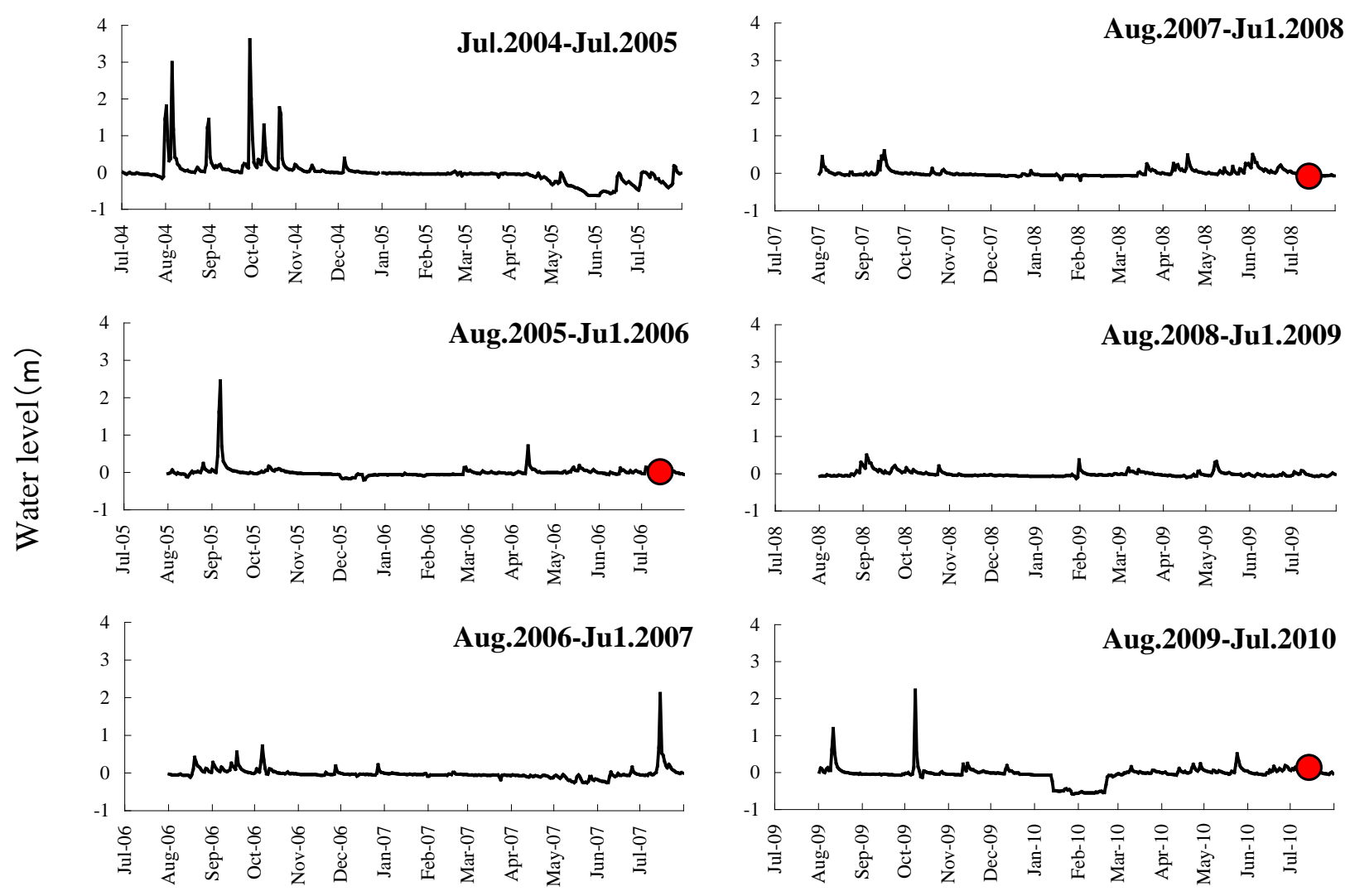

Figure 7. Water levels (2004-2010) in the Kushida River (Kushida bridge). ※๐ indicates the period of investigation.

Table 1. Areas of the plant communities in the tidal flats of the Kushida River estuary.

\begin{tabular}{cccc}
\hline Community & 2006 & 2008 & 2010 \\
\hline Suaeda maritima & 0 & 3906 & 2578 \\
Artemisia fukudo & 255 & 2726 & 10,396 \\
Zoysia sinica & 1255 & 986 & 1385 \\
Carex scabrifolia & 0 & 0 & 22 \\
Phragmites australis & 5639 & 6113 & 4846 \\
Phragmites australis- & 356 & 0 & 0 \\
Phacelurus latifolius & 18,490 & 18,597 & 18,560 \\
Phacelurus latifolius & 793 & 735 & 579 \\
Ischaemum anthephoroides & 630 & 630 & 149 \\
Rosa luciae & 0 & 78 & 749 \\
Other coastal plant & 265 & 113 & 261 \\
Vitex rotundifolia & 1605 & 1605 & 1502 \\
Hibiscus hamabo & 350 & 539 & 681 \\
Solidago canadensis & 649 & 649 & 724 \\
Other herbaceous plant & 91 & 91 & 215 \\
Woody plants & 30,378 & 36,768 & 42,647 \\
\hline Sum Area (m ${ }^{2}$ ) & & &
\end{tabular}

2004 and was generally lower, at $200-600 \mathrm{~m}^{3} \cdot \mathrm{s}^{-1}$, in September 2005, July 2007, September 2008 and August and October 2009 (Figure 8).

Regarding the number of days per normal water level category, including before and after the investigation period (July 2004-July 2010), the overflow warning water level $(3.5 \mathrm{~m})$ and flood fighting corps standby water level (3.0 m) each occurred on one day in 2004, with the water volume exceeding $1000 \mathrm{~m}^{3} \cdot \mathrm{s}^{-1}$ and $1500 \mathrm{~m}^{3} \cdot \mathrm{s}^{-1}$, respectively. A water level of 2-3 m occurred on one day each in 2004, 2005, 2007 and 2009, with a water volume of approximately $480-690 \mathrm{~m}^{3} \cdot \mathrm{s}^{-1}$. A water level of $1-2$ $m$ was observed during eight days in 2004 and one day each in 2005 and 2009, with an average flow volume of $230-280 \mathrm{~m}^{3} \cdot \mathrm{s}^{-1}$. Water levels of $0-1 \mathrm{~m}$ occurred in all years (Table 3 ).

\section{DISCUSSION}

\section{Changes in the Degree and Frequency of Disturbance on Suaeda maritima, Artemisia fukudo Communities}

The areas of the annual salt marsh plant communities of Suaeda maritima and Artemisia fukudo in the branch river of the Kushida River were very small in 2006 (Table 1, Figure 5). In 2006, before the investigation period, 
Table 2. Changes in the area of the annual salt marsh plant communities (Suaeda maritima, Artemisia fukudo).

\begin{tabular}{|c|c|c|}
\hline Vegatation change & $2006 \rightarrow 2008$ & $2008 \rightarrow 2010$ \\
\hline \multicolumn{3}{|l|}{ Soil sedimentation disturbance area } \\
\hline Bare ground $\rightarrow$ Suaeda maritima community & 4554.1 & 2550.3 \\
\hline Bare ground $\rightarrow$ Artemisia fukudo community & 1669.2 & 9515.9 \\
\hline Suaeda maritima community $\rightarrow$ Artemisia fukudo community & - & 2686.0 \\
\hline Suaeda maritima community $\rightarrow$ Perennial plant community & - & 557.5 \\
\hline Artemisia fukudo community $\rightarrow$ Perennial plant community & 3.0 & 275.3 \\
\hline \multicolumn{3}{|l|}{ Soil erosion disturbance area } \\
\hline Suaeda maritima community $\rightarrow$ Bare ground & - & 1132.7 \\
\hline Artemisia fukudo community $\rightarrow$ Bare ground & 0.04 & 1202.1 \\
\hline Artemisia fukudo community $\rightarrow$ Suaeda maritima community & - & 107.5 \\
\hline Perennial plant community $\rightarrow$ Suaeda maritima community & 1.2 & 4.8 \\
\hline Perennial plant community $\rightarrow$ Artemisia fukudo community & 344.5 & 405.2 \\
\hline \multicolumn{3}{|l|}{ No vegetation change area } \\
\hline Suaeda maritima community $\rightarrow$ Suaeda maritima community & - & 179.1 \\
\hline Artemisia fukudo community $\rightarrow$ Artemisia fukudo community & 252.7 & 681.4 \\
\hline Soil sedimentation disturbance area & 6226.3 & 15585.0 \\
\hline Soil erosion disturbance area & 345.7 & 2852.3 \\
\hline No vegetation change area & 252.7 & 860.5 \\
\hline
\end{tabular}

※Growing location of Suaeda maritima and Artemisia fukudo determinated by literature of Sato et al. (2007), Araki et al. (2009).

Table 3. Number of days and average water volumes of each normal water level category, including before and after the investigation period (July 2004-July 2010).

\begin{tabular}{|c|c|c|c|c|c|c|c|c|c|c|c|c|c|c|c|}
\hline \multirow[b]{2}{*}{$\begin{array}{l}\text { Water level } \\
\qquad(\mathrm{m})\end{array}$} & \multirow[b]{2}{*}{ Normal water level } & \multicolumn{2}{|c|}{2004} & \multicolumn{2}{|r|}{2005} & \multicolumn{2}{|c|}{2006} & \multicolumn{2}{|c|}{2007} & \multicolumn{2}{|c|}{2008} & \multicolumn{2}{|c|}{2009} & \multicolumn{2}{|c|}{2010} \\
\hline & & Days & $\begin{array}{c}\text { Water } \\
\text { volume } \\
\text { (Ave) }\end{array}$ & Days & $\begin{array}{c}\text { Water } \\
\text { volume } \\
\text { (Ave) }\end{array}$ & Days & $\begin{array}{c}\text { Water } \\
\text { volume } \\
\text { (Ave) }\end{array}$ & Days & $\begin{array}{c}\text { Water } \\
\text { volume } \\
\text { (Ave) }\end{array}$ & Days & $\begin{array}{c}\text { Water } \\
\text { volume } \\
\text { (Ave) }\end{array}$ & Days & $\begin{array}{c}\text { Water } \\
\text { volume } \\
\text { (Ave) }\end{array}$ & Days & $\begin{array}{c}\text { Water } \\
\text { volume } \\
\text { (Ave) }\end{array}$ \\
\hline 3.5 & $\begin{array}{c}\text { Overflow warning } \\
\text { water level }\end{array}$ & 1 & 1517.0 & 0 & - & 0 & - & 0 & - & 0 & - & 0 & - & 0 & - \\
\hline 3 & $\begin{array}{l}\text { Flood fighting corps } \\
\text { standby water level }\end{array}$ & 1 & 1014.8 & 0 & - & 0 & - & 0 & - & 0 & - & 0 & - & 0 & - \\
\hline $2-3$ & & 1 & 560.5 & 1 & 690.1 & 0 & - & 1 & 566.4 & 0 & - & 1 & 488.5 & 0 & - \\
\hline $1-2$ & & 8 & 379.5 & 1 & 363.5 & 0 & - & 0 & - & 0 & - & 1 & 226.3 & 0 & - \\
\hline $0-1$ & & 131 & 25.9 & 72 & 10.6 & 167 & 13.1 & 76 & 12.9 & 154 & 18.8 & 114 & 22.6 & 103 & 17.4 \\
\hline
\end{tabular}

※The normal level: Water level data of Kushida River (Kushida bridge). Water information system of the Ministry of Land, Infrastructure, Transport and Tourism, Japan, http://www.river.go.jp/. ※Flood fighting corps standby level: Preparation of the flood fighting corps and river management inspection. ※Overflow warning water level: Mobilization of the flood fighting corps and river management inspection at flood time. ※ It means that “-” indicates a lack of data. 

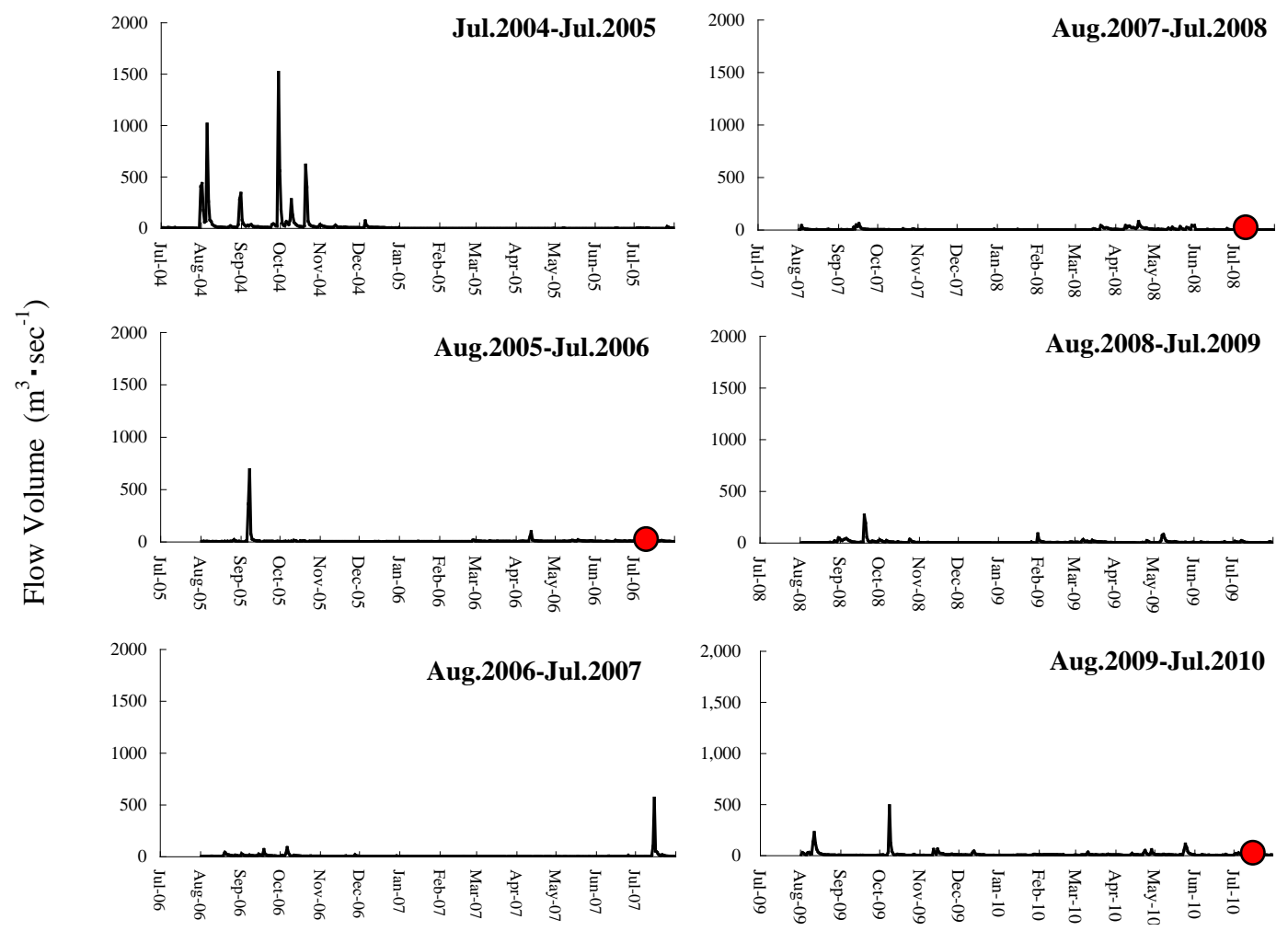

Figure 8. Flow volumes (2004-2010) in the Kushida River (Kushida bridge). $※$ indicates the period of investigation.

the overflow warning water level $(3.5 \mathrm{~m})$ and flood fighting corps standby water level $(3.0 \mathrm{~m})$ each occurred on one day, in August 2004 and October 2004, respectively; at those times, the water volume exceeded 1000 $\mathrm{m}^{3} \cdot \mathrm{s}^{-1}$ and $1500 \mathrm{~m}^{3} \cdot \mathrm{s}^{-1}$, respectively (Table 3 ).

Disturbances of this scale were not observed during the investigation period. With respect to the growth environment of these species, Suaeda maritima disseminates its seed via the tide [15] and may form soil seed bank [16]. The Suaeda maritima community occurs at low elevations that are disturbed by flooding at high tide [3]. In addition, the Suaeda maritima community prefers the fine gravel and pebble gravel substrate that occurs below the spring high tide level [17]. In contrast, Artemisia fukudo grows in the mud substrate that is flooded by seawater during the high tide in the river tidal area, and it is a winter annual plant that flowers during the autumn [18-20].

As the annual salt marsh plant communities of Suaeda maritima and Artemisia fukudo grow in low areas disturbed by flooding, erosion of the estuarine tidal flat can readily occur when the water level reaches either the overflow warning water level $(3.5 \mathrm{~m})$ or the flood fighting corps standby water level $(3.0 \mathrm{~m})$ and when the water volume exceeds $1000 \mathrm{~m}^{3} \cdot \mathrm{s}^{-1}$. Therefore, it seems likely that the re-establishment of the plant community and the growth of these species are delayed until new substrate is formed by sedimentation. Following a major flooding disturbance, the Suaeda maritima community expanded substantially to $3609 \mathrm{~m}^{2}$ in 2008, and the Artemisia fukudo community expanded significantly to $2726 \mathrm{~m}^{2}$ in 2008 and to 10,396 $\mathrm{m}^{2}$ in 2010 (Table 1, Figure 5). A water level of 2 - 3 m occurred between July and October on one day each in 2005, 2007 and 2009, when the average water volume was $488.5,566.4$ and $690.1 \mathrm{~m}^{3} \cdot \mathrm{s}^{-1}$, respectively (Table 3 ). With respect to the amount of change in vegetation in the annual salt marsh plant community, the greatest change in area from bare ground to the Suaeda maritima community occurred between 2006 and 2008, and the changes in area from bare ground to the Artemisia fukudo community and from the Suaeda maritima community to Artemisia fukudo community were highest between 2008 and 2010 (Table 2). With respect to the elevations of the Suaeda maritima and Artemisia fukudo communities, dense growth of the Suaeda maritima community occurred at an elevation (T.P.:Tokyo Peil) between 0.785 and 1.063 m [17]. Dense growth of the Artemisia fukudo community occurred at a T.P of approximately $1.1 \mathrm{~m}$ [21]. The fructification rate of Artemisia fukudo was higher at a T.P of $1.3-1.5 \mathrm{~m}$ than at $1.0 \mathrm{~m}$ or less. This result may reflect the short period of pollination and the overabundance of pollen at lower elevations, where the inundation period is extensive [22]. We suggest that, although we found on the 
ground that Artemisia fukudo and Suaeda maritima were co-occured, Artemisia fukudo grows more readily than Suaeda maritima at higher elevations. Consequently, it seems likely that, following the repeated disturbances of water levels of $1-3 \mathrm{~m}$ and flow volumes of $480-700$ $\mathrm{m}^{3} \cdot \mathrm{s}^{-1}$ over the bare ground eroded by massive flooding in 2004, the Suaeda maritima community was established on the higher ground formed by the sediment transported from upstream and the sea during high tides and subsequently deposited. In addition, when this same level of disturbance occurred, Artemisia fukudo germinated and grew on the ground that was made higher by the sediment deposited on the Suaeda maritima community.

Based on the extent of vegetation change due to disturbance that occurred over the entire study site, the area of soil sedimentation disturbance was approximately $20 \%$ between 2006 and 2008 and expanded to approximately $45 \%$ between 2008 and 2010. The area of soil erosion disturbance was 4.8\% between 2006 and 2008 and expanded to approximately 19.3\% from 2008 to 2010 (Figure 6). The study site was strongly influenced by the disturbance activities of sedimentation and erosion between 2008 and 2010 relative to the period between 2006 and 2008. Because the area was strongly influenced by sedimentation, we postulate that the area of the Artemisia fukudo community expanded to a greater extent than the Suaeda maritima community.

\section{ACKNOWLEDGEMENTS}

We wish to express our sincere gratitude to Mr. Kiyotaka Asami of Ecosystem Conservation Society Japan and Mr. Kiyoshi Uchiyama of Specified nonprofit organization Mie nature conservation center, who cooperated with the study.

\section{REFERENCES}

[1] Mie Prefecture, Environmental Conservation Agency. (2005) Threatened wildlife of Mie 2005. Plants Mushroom, Mie Prefecture.

[2] Ministry of the Environment Government of Japan (2007) Revision, list of threatened wildlife of Japan. Wildlife Division, Nature Conservation Bureau, Ministry of the Environment, Tokyo.

[3] Kaneko, K., Yabe, T. and Nohara, S. (2005) Vegetation changes and topographic feature in the delta of Obitsu River in Tokyo Bay. Japanese Journal of Landscape Ecology, 9, 27-32.

[4] Araki, S. and Kunii, H. (2011) Halophyte communities along the estuarine riverside of Ota river. Bulletin of the Hoshizaki Green Foundation, 14, 251-256.

[5] Ohnuma, K., Endo, M., E, Amano, K. and Kishida, H. (2011) Analysis of vegetation distribution and its relation to tidal oscillation in riverine estuaries. Japanese Journal of Hydroscience and Hydraulic Engineering, 55, 1345-
1350.

[6] Delaune, R., Patrick, W. and Buresh, R. (1978) Sedimentation rates determined by 137 Cs dating in a rapidly accreting salt marsh. Nature, 275, 532-533. http://dx.doi.org/10.1038/275532a0

[7] Deleeuw, J., Demunck, W., Olff, H. and Bakker, J. (1993) Does zonation reflect the succession of salt marsh vegetation-A comparison of an estuarine and a coastal island marsh in the Netherlands. Acta Botanica Neerlandica, 42, 435-445.

http://dx.doi.org/10.1111/j.1438-8677.1993.tb00719.x

[8] Dijkema, K.S. (1997) The influence of salt marsh vegetation on sedimentation. In: Eisma, D., Ed., Intertidal Deposits River Mouths, Tidal Flats and Coastal Lagoons, CRC Press, Boca Ration, 403-414.

[9] Hatton, R.S., Delaune, R.D. and Patrick, W.H.J. (1983) Sedimentation, accretion, and subsidence in marshes of Barataria Basin, Louisiana. Limnology and Oceanography, 28, 494-502. http://dx.doi.org/10.4319/lo.1983.28.3.0494

[10] Kaneko, K. and Nohara, S. (2013) Vegetation communities in estuarine tidal flats in the different river and basin environments of the four major rivers of Ise Bay (Suzuka, Tanaka, Kushida), Mie prefecture, Japan. Open Journal of ecology, 3, 205-213.

[11] Water Information System in Ministry of Land, Infrastructure, Transport and Tourism, Japan. http://www1.river.go.jp/

[12] Miyawaki, A., Okuda, S. and Suzuki, N. (1975) Vegetation in der Umgebung der Bucht von Tokyo. Institution for Transport Policy Studies, Tokyo.

[13] Kusanagi, T. (1986) Diagnosis of primary color weed. Rural culture association, Tokyo.

[14] Shimizu, T. (2003) Naturalized plants of Japan. HEIBONSHA, Tokyo.

[15] Huiskes, A.H.L., Koutstaal, B.P., Herman, P.M.J., Beeftink, W.G., Markusse, M.M. and Munck, W.D.E. (1995) Seed dispersal of halophytes in tidal salt marshes. Journal of Ecology, 83, 559-567. http://dx.doi.org/10.2307/2261624

[16] Hutchings, M.J. and Russel, P.J. (1989) The seed regeneration dynamics of an emergent salt marsh. Journal of Ecology, 77, 615-637. http://dx.doi.org/10.2307/2260974

[17] Kamata, M. and Ogura, Y. (2006) Habitat evaluation for plant communities as a salt marsh in the Naka River, Shikoku Japan. Ecology and Civil Engineering, 8, 245-261. http://dx.doi.org/10.3825/ece.8.245

[18] Kitamura, S. (1942) Ecology of Artemisia fukudo. Acta Phytotaxonomica et Geobotanica, 11, 59-60.

[19] Kitamura, S., Murata, G. and Hori, M. (1963) Colored illustrations of herbaceous plants of Japan Vol.1, Sympetalae, reserved edition. HOIKUSHA Publishing, CO., LTD., Osaka.

[20] Makino, T. (1996) Revised Makino’S illustrated Flora in colour. Gamopetalae. In: Ono, M., Ooba, H., Nishida, M. and Murata, J., Eds., Hokuryukan Publishing, CO., LTD., Tokyo.

[21] Satou, Y., Fujita, F. and Ohnuma, K. (2007) Classification 
from river engineering viewpoint of the river in flats of tidal flats in Otagawa discharge channel. Conference Abstract in Annual Scientific Conference of Japanese Society of Civil Engineers, 62, Division, 127-128.

[22] Araki, S., Kunii, H. and Suyama, S. (2009) Growth envi- ronment of salt marsh plants well established in artificial channel. Proceedings of the 53th Annual Meeting of the Chugoku-Shikoku Branch of the Ecological Society of Japan, 16-17 May 2009. 